\title{
The Built Environment of Kampung Arab Sugihwaras Pekalongan
}

\author{
Astari Wulandari ${ }^{1, *}$, Loekman Mohammadi ${ }^{1}$, and Anwar ${ }^{1}$ \\ ${ }^{1}$ Architecture Study Program, University of 17 Agustus 1945 Semarang, Indonesia
}

\begin{abstract}
Since the arrival of Arabian ethnic to Sugihwaras, they settled and built their own neighborhood identity. The built environment is an example of a system on which human beings seek to express their own identity as a collective group. Every built environment consists of distinctive features that relate to social, cultural, economic and environmental parameters inherent in that particular built-environment (Al-Hokail, 1995). Based on that background, the research question of this study is "what is the distinctiveness of built environment in Kampung Arab Sugihwaras Pekalongan?". The purpose of this article is to identify and explain the built environment in Kampung Arab Sugihwaras by its social and physical parameters. Using both qualitative and quantitative approach, this article examines the social parameters by its four social scales: neighborhood, family and individual, the physicalparameters by its urban fabrics. The result shows that community who lives in Kampung Arab Sugihwaras especially the Arabian descendant preserving Islamic value in their social lives. But, modern urban culture faded some social rules away. While the Kampung Arab Sugihwaras urban fabric shows that neighborhood had grid pattern with two inner main streets and buildings withIndische Architecture style in that corridors. The further result shows the street hierarchy by overlapping the social and physical parameters analysis.
\end{abstract}

Keywords: Kampung Arab Sugihwaras, built environment, social, and physical

\section{Introduction}

The trade route between Hadhramaut and Nusantara has been established since the 7th century shortly after the entry of Islam (Arnold, 1935). Within the next period, the Hadhramaut's came gradually until reached its peak in 18 century. Based on statistic record in 1985, there was six big colony of Arabian ethnic in Java. They settled in Batavia, Tegal, Pekalongan, Semarang, Surabaya, and Madura (Van den Berg, 1988).

Pekalongan became a destination since it well known as a paddy and spices producer (Yudhohusodo dkk, 1991). There were ancient port in Pekalongan, Bandar and Doro ports which more reputable than Pekalongan itself. The existence of that port in the past is corroborated by a note in 18 century.

It stated that a Chinese group (which call Ma Huan) who stayed over in Kampung Sampangan which located in near Kupang River springhead. That location became a place where the loading boat tethered from the port (Asa,, 2009).

Islam came to Pekalongan through three phase. First phase happened in 14 to 15 century which related to the Chinese and Arabian populations growth. Second phase happened in 15 to16 century when Islam brought by Wali Songo. The third phase, Islam was come along with Hadhramaut Ulama' and local Ulama' who known as Alawiyyin Ulama' (Asa, 2009).

Sugihwaras is a district where Arabian ethnic inhabitant mostly found in Pekalongan. The Arabian ethnic who brought their own culture, tradition, and religion influences the housing layout and built environment. Every builtenvironment consists of distinctive features that relates to social, cultural, economic and environmental parameters inherent in that particular built-environment (Al-Hokail, 1995).

\section{The Problem}

The buildings with Indisch Empire architecture style still found in Kampung Arab Sugihwaras, especially in Surabaya street. Nowadays, the city development and economic growth influence the built environment in Kampung Arab Sugihwaras directly. Most of inhabitant are enterpreneur who run family bussines. Therefore, there was a change in their houses. Both on the layout and building façade. According to the Buchler (1979), the built environment reflect who we are and what our stand should be towards the natural world. Built environment is the focal point of a network of commitments and opportunities - a way of life - that leave the present and future generations indebted. Based on its importance and the background of Kampung Arab Sugihwaras, analyzing built environment by its social and physical parameters is necessary.

*Corresponding author: ast_wulandari@yahoo.com 


\section{Social Principles in Traditional Islamic Built Environment}

For Muslim, Islamic sha'ria's should practice in their lives as a commitments and responsibilities. Mortada (2003) analyzing the traditional Islamic built environment by its social framework and classified into four scales: society, neighborhood, family, and individual.

In Islam, social solidarity ('ummah) is the foundation to build the strong community. As proposed in Mortada's social framework, it evolved to the social interaction and social justice. Muslims as a big community should notice these principles in their daily life to represent their commitment and faith in Islam. They also suggest avoiding any communal action which unties the social solidarity between them.

Neighborliness have important rule in community as stated by Mortada (2003),

"Islam exceptionally looks at neighborliness as the backbone of 'ummah. This is exhibited in the provision of a set of ethics which themselves are obligations that enhance and control neighbourliness. These ethics are found in two main principles: strong neighborly relationships and the preservation of neighbors' rights."

The importance of neighborliness narrated in Al-Qur'an as well. It stated to do good to parents, kinsfolk, orphans, those in need, neighbors who are near, neighbors who are far, the companion by your side, the wayfarer (ye meet), and that your right hands possess' (Qur'an, Su. 4:36). Based on that rule, Muslims are required to maintain the good relationship with the neighbors.

At the family scale, the social principles could be identified by the strength of family ties and the existence of extended family. Family became an important foundation in Islam society especially its role to build entire socio-cultural structure. Moreover, a family is a self-sustaining institution which ensures ideological and cultural stability over the entire spectrum of society on the one hand, and in time, past, present and future on the other (Mortada, 2003).

An Individual represents the Islam society where every Muslims have to show the finest quality of behavior and against individualistic lifestyle (Levy, 1938). Muslim individual should sustain an amicable relationship with his fellow Muslims and be humble in his behavior and lifestyle and moderate in spending (Mortada, 2003).

\section{Physical Principles in Traditional Islamic Built Environment}

The application of Islamic value in built environment and Islam cities reflected on particular principles which heading to elevate the Islamic social framework. Both, social and physical principles build upon Al-Qur'an and as-sunnah while another value and social norms growth in Muslims society. The influence of social principles Islamic to the built environment is clearly state by Mortada (2003),

"From the birth of Islam in the seventh century until the end of the nineteenth century Islamic law was a major force shaping that environment, providing stability and continuity in its urban planning and design",

Based on those phenomena, Mortada (2003) analyzing the physical principles by its scale: natural environment, the urban environment and the house.
There is a limitation in this article, particularly in analyzing scale of physical princ0iples. In this article, to analyze the physical principles of built environment limited on the neighborhood and the house scale.

\section{Built Environment}

The variables which related to the Muslim built environment are the Muslim house form that adjacent and clustered (AlShishtawe, 1982), street hierarchical function that accommodate the needs (Al-Bukhari, 1960), spatial hierarchy of open space that changes its size character and function (Mortada, 2003), and the mosque existence based on its hierarchy and function (Mortada, 2003).

\section{The House}

By Al-Quran and As-Sunnah, Islam delivers a systematic review that indicates the principles to build or to develop a house. The Muslim houses represent the family member's faith of Islam and its value. It comprise the privacy setting, the straight barrier between personal and social live inside the house (Patherbridge, 1987), the inner open space and room organizing (Mortada, 2003).

\section{Hablumminallah, Hablumminannas, and Hablumminal'alamien Principles}

The application of Islam principles in architecture also mention by Munichy (2010). As a Muslim architect, the application of Islam principles in architecture should be ensure the relation between God, Human, and Environment. Hablumminallah describe the relation between human and God. Hablumminannas is the relation between human and another human (the social life). Hablumminal'alamien describes the relation between human and the environmental. That concept will produce the Islamic architecture concept which stands on Al-Quran and Hadith. This concept deliver five important variables, function, form, technique, safety, and comfortably which all of them have consider the contextually and efficiency.

\section{Methodology}

This article use both quantitative and qualitative approach. The quantitative method is used to analyze the social principles in Kampung Arab Sugihwaras by its variable. The qualitative approach is used to describe and analyze physical principles which related to the built environment in Kampung Arab Sugihwaras.

The random sampling technique is used to analyze the social characteristic by using the above theory as a framework. The informants are the inhabitant of Kampung Arab Sugihwaras. While to analyze the physical principles, observation method is used to identify the physical character.

\section{The Beginning of Sugihwaras}

The arrival of Arab community from Hadhramaut in Pekalongan dominated by Sayyid, a called for the highest 
society who capable in religious knowledge and had a settle economic condition Van den Berg (1989) and Steenbrink (1984). They married to the headman daughter and became the core of big colony in Sugihwaras.

Habib Hussein Al-Attas was the first one who came to Sugihwaras in year 1800. At that time Sugihwaras was a jungle. He built a mosque as a place to pray and a place to introduce Islam as well. That act represented what Rasullullah did when hijjrah. The mosque became an embrio to the social interaction in Sugihwaras (Astuti, 2002). Nowadays, that mosque is well known as Wakaf Mosque which located in Surabaya Street.

The name Sugihwaras developed in colonial era. Sugihwaras is consists of two words in Javanese, sugih and waras. History of Sugihwaras related to the existence of pawnshop and Doctor Agus Mulyadi house, at the past. The pawnshop had important role, supporting habitant financial fund. Most of habitant was a batik and sarong trader and they avoid the interest-bearing loans from the bank to expand their business as obedience to their faith in Islam. Furthermore, the colonial bank would be confiscating the habitant asset if they could not afford to pay the loan and interest. Meanwhile, dr. Agus Mulyadi was well known as a generous and his humanity. The sick habitants prefer went to the doctor's house than to the hospital which run by Dutch Government (Astuti, 2002).

Based on that background, the history of Sugihwaras describes the convenience of funding so that the habitants became wealthy (sugih). While the generosity and humanity from the medical doctor support the people's health (waras).

\section{Social Life of Kampung Arab Sugihwaras}

To analyze the social condition in Kampung Arab Sugihwaras, in this article is classified in society, neighborhood and family.

\section{Society}

The dominance of Islam in Arab Sugihwaras makes Islamic culture deeply rooted in society. All of respondent was agree that charity (sedekah) as a habit, hospitality to guest, and good deeds to others reflected the strong social interaction. It state on Al-Qur'an.

And serve Allah. Ascribe no thing as partner unto Him. (Show) kindness unto parents, and unto near kindred, and orphans, and the needy, and unto the neighbor who is of kin (unto you) and the neighbor who is not of kin, and the fellowtraveller and the wayfarer and (the slaves) whom your right hands possess. Lo! Allah loveth not such as are proud and boastful (QS 4:36)

One of the community act that show the strong social interaction in Sugihwaras is a charity to the poor which organized by the locals organization and the toddler as well by distributing the formula milk and foods. Related to charity, all of respondent understand that charity is required to every Muslim which not limited to the money and materials. Abu Hurairah (ra) reported that the Messenger of Allah (sas) said

"Every joint of a person must perform a charity each day that the sun rises: to judge justly between two people is a charity. To help a man with his mount, lifting him onto it or hoisting up his belongings onto it, is a charity. And the good word is a charity. And every step that you take towards the prayer is a charity, and removing a harmful object from the road is a charity." (Al-Bukhari and Muslim)

\section{Neighborhood}

Islam obligates to enhance and control neighborliness. Prophet Muhammad said that,

"The best of companions with Allah is the one who is best to his companion, and the best of neighbors with Him is the one who is best to his neighbor. He also said, "The one who harms his neighbor will not enter Paradise." (Al-Bukhari and Muslim)

Neighborhood life reflected the people's social condition by its norms and another intangible value which indirectly take control. In Kampung Arab Sugihwaras 81\% respondent had relatives who lives around Sugihwaras district. That phenomenon shows likely to strengthen neighborliness ties. Occasionally they visit the neighbor around to greet or deliver the food. They believe the good deeds not only limited to the next door neighbor, but also extended to those further away (Mortada, 2003).

Related to the preservation of neighbors' rights, the habitants of Kampung Arab Sugihwaras showed when build a building. An individual who plan to build usually ask permission to the neighbor next door and the neighbors whose wall coincide with the building to be built. The pictures below show the building height condition that most of buildings in Kampung Arab Sugihwaras have similar height.

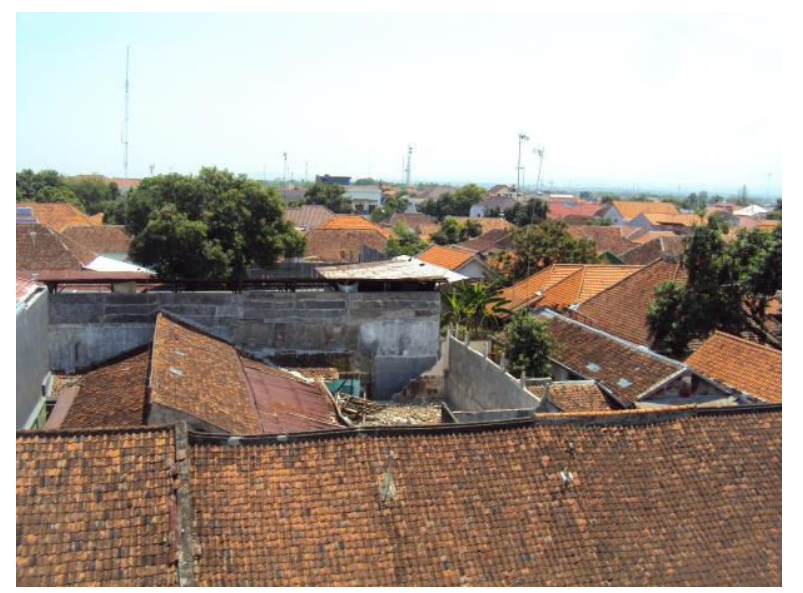

Fig. 1. The Similar Building Height.

The similar building heights in Kampung Arab Sugih Waras represent the equality. There is no building which height is block the air circulation and the sunlight to another building. Like The Prophet also said (Karim, 1938 in Mortada, 2003),

'Do not block his (the neighbor's) air by raising your building higher without permission. Harass him not. Give him a share when you buy fruit or at least do not throw the peelings outside the door so offending your neighbor.'

\section{Family}

Family had an important role as a foundation of socialcultural structure in Islam to the past, present, and the future. 
The family bond in Sugihwaras identified by its strong family ties and the big family concept.

In the tradition of Arab descendants, in determining the spouse is preferred to choose a person who is a relative or a distant relative to avoid marriage with someone who is not of Arab descent. This picture bellow showed the marriage scheme in the highest social class (Sayyid) in Pekalongan.

But now, there is a social transformation in spouses determining in Arab community in Sugihwaras. The analysis found $17 \%$ respondent who agreed to married to their relatives.

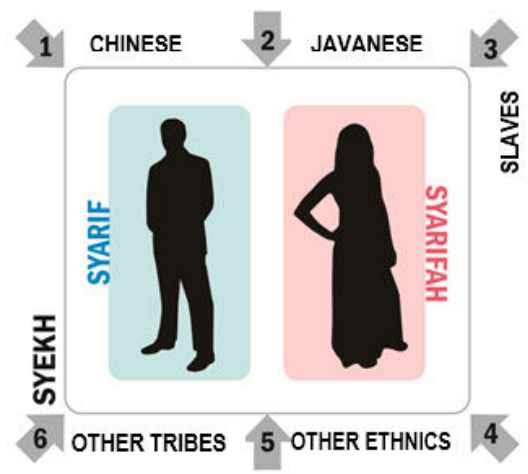

$1,2,6$

The Sayyid marriage to the Chinese, Javanese, and other ethnics is acceptable but rarely happened

\section{$3,4,5$}

The marriage will triggering the contradiction and the married couple will be an outcast from the social class

Fig. 2. The Sayyid Marriage Scheme (Redraw from Astuti, 2002).

In Islam city, mostly found a house where three or four generation lives. Ahmed (1987) stated that extended family consists of relations emerging from consanguinity, affinity and foster-nursing. On the contrary, now in Sugihwaras, $61 \%$ respondent thought the extended family is not a common thing.

\section{Sugihwaras Built Environment}

Sugihwaras built environment characteristic will be explained by two scales; neighborhood scale by its pattern, circulation, and open space; house scale by its privacy and spatial order. In addition, in this chapter will explain the role of Wakaf Mosque to Sugihwaras as well.

\section{Neighborhood}

\section{The Pattern}

The neighborhood physical pattern would illustrate the conformity between physical and social space. Based on the figure ground, Sugihwaras tend to be homogeneus.

Kampung Arab Sugihwaras have a gridiron pattern where two main roads, Surabaya Street and Semarang Street, split this district. Most of the building oriented to the street. In both corridors, the atmosphere of the area is pretty quiet, not many motor vehicles passing by. Most of the users of the vehicle are the people living in the vicinity. In the area of life can be captured the impression that the area is less "alive" because the activity of most people of Arab descent reside in the house.

Both corridors are formed from ranks of road-oriented building. Most of the buildings on both corridors have an Indische Empire architectural style. Even there are found some buildings that change on its facade. On the next page shows the corridors of Surabaya and Semarang which are dominated the homes of Arab descendants.

\section{Circulation}

Based on classification there is local roads, neighborhood roads and alleyways. The road network classified to the local road is Sultan Agung Street, Bandung Street, Patiunus Street and Agus Salim Street. The main network is a road with asphalt pavement with a width of about 4 - 5 meters. While the road network that classified to neighborhood roads is the corridor of Semarang Street and Surabaya Street in the form of asphalt road with width 3.5 meters. For alley and dead end roads are scattered throughout the region. In general, the alley in the area has a width of less than 2.5 meters and most can only be passed by bikers, cyclists, and pedestrians. Based on observation, the entire street in Sugihwaras had two functions, supporting the accessibility and becoming the social space, even though the social interaction intensity mostly found in alley around Sugihwaras district.

\section{Open Space}

There is no open public space found in Sugihwaras. Therefore to celebrate the important event (celebrating the Independence Day, or religious event) the street is used. Surabaya Street is the place where the important event (neighborhood event, local event, or regional event) was held. While the alley limited to the neighborhood event.

\section{The House}

The similarities of architectural forms of the Arab descendants of Sugihwaras begin by the three rich Arab families, the Argubi, Yahya, and bin Shihhab families. At that time home rental businesses was a promising business and deliver high profits. The three rich families built many houses in Kampung Arab Sugihwaras, in addition to rent also for the habitable. The similarities in architecture style, colonial style, indicated that house developing at past duplicated the architectural recent styles (Astuti, 2002). Van den Berg (1989) stated the same idea. The Arab community who migrated to Pekalongan was a rich tradesman. The implication of their wealth, their houses built by adapted the recent architecture style. 


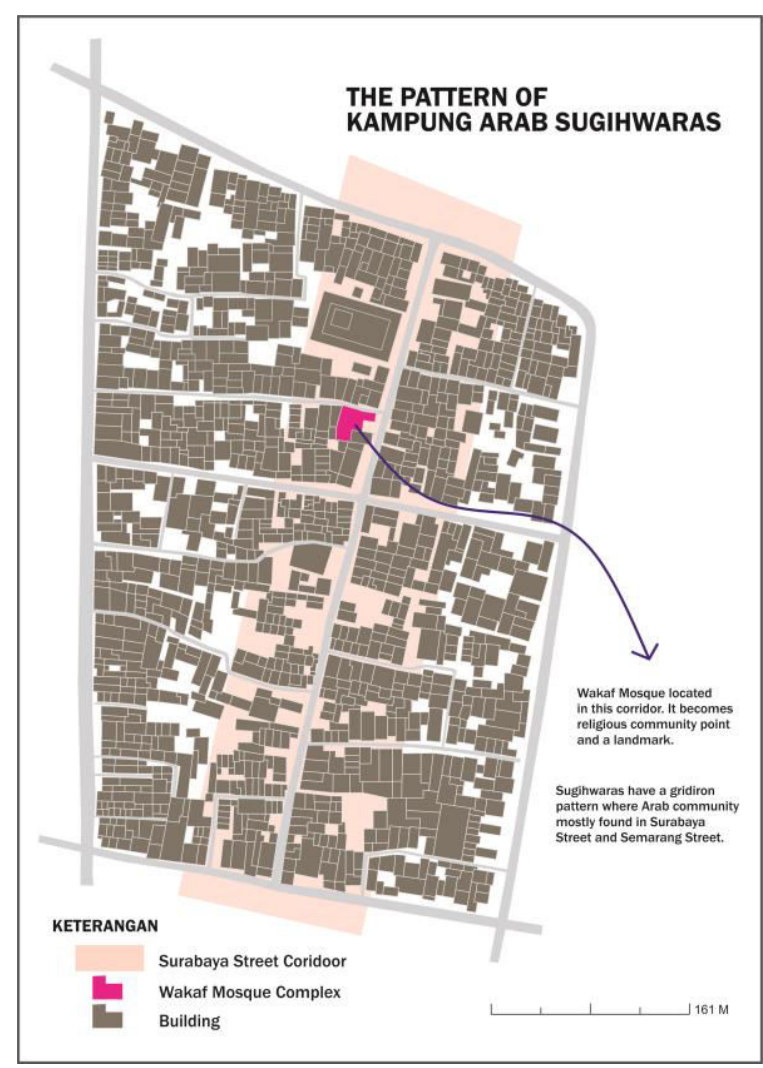

Fig. 3. The Pattern of Kampung Arab Sugihwaras.

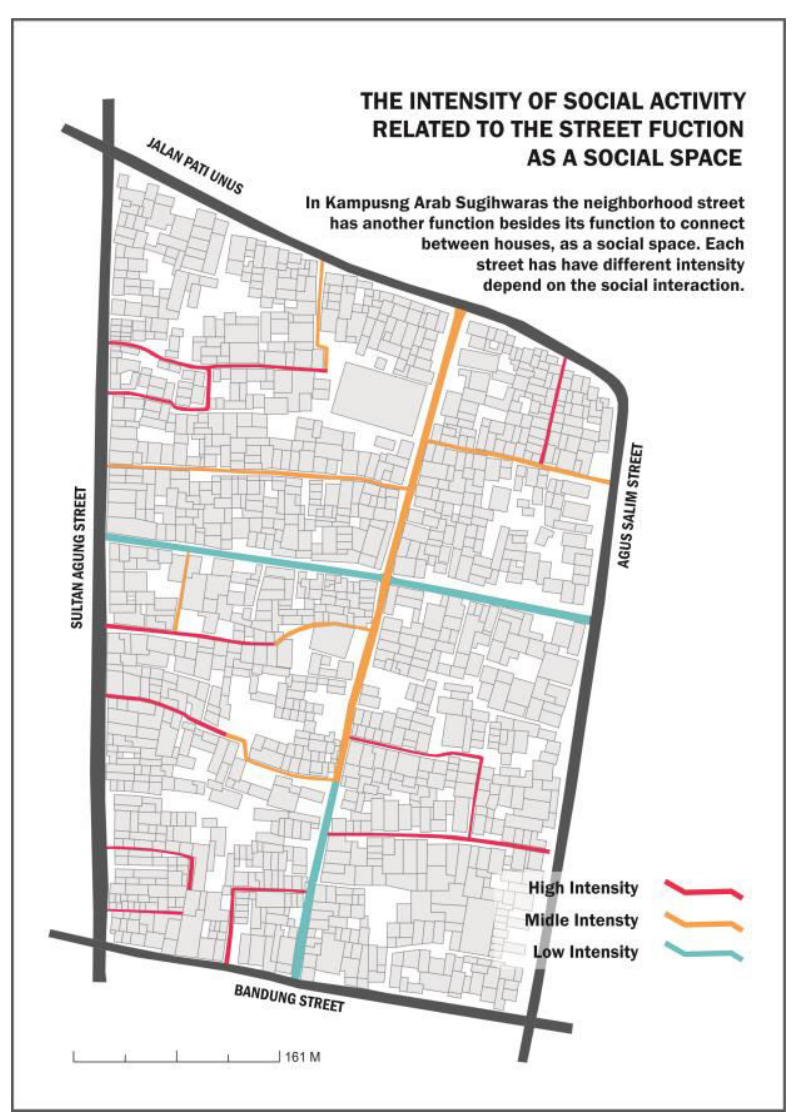

Fig. 4. The Intensity of Social Activity Related to the Street Fuction as a Social Space.

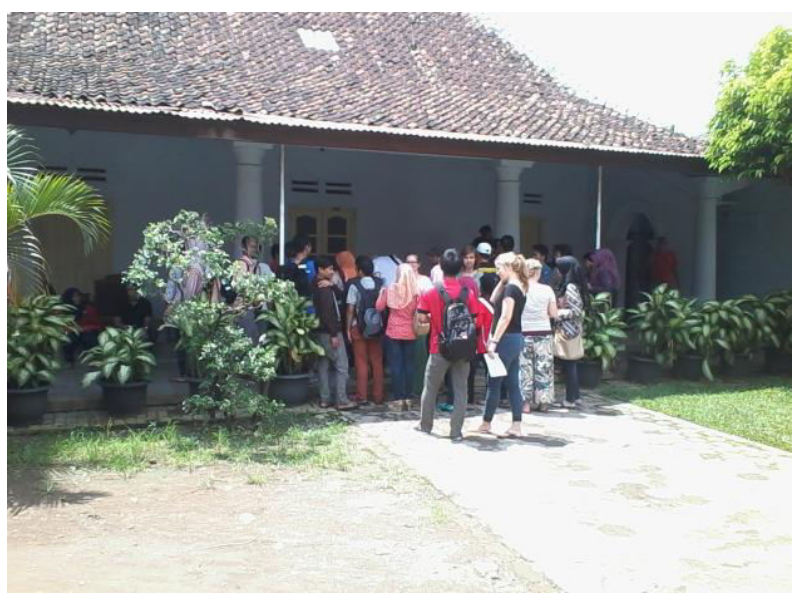

Fig. 5. Influence of Indische Empire Style.

\section{Spatial Organization}

The spatial organization in the homes of Arab descendants is based more on social and personal interests, rather than on activities that take place in the home. For that the spatial order inside the house is based on the concept of hijab. The concept of hijab is not only related to social and personal life, but the concept also relates to the personal lives of each resident (Astuti, 2002).

That concept manifestation seen on the spatial zoning based on its character, private or public. Every house in Kampung Arab Sugihwaras had separated guest room and family room where usually devided by another door or partition. Bedroom as private room is well planned also. Parents' bedroom and children bedroom are separated as well.

\section{Privacy}

In the past, the existence of an alternative door in the home of the Sugihwaras Arab Village community was used by women to go into the house or referred to as a woman's path (Astuti, 2002). Generally behind the door - the alternative is a small road like a hallway. There is a rule for every Arab woman not to enter the house through the front door, if the non-mahram guest is visiting. It is based on the presence of male guests who are welcomed by the house. The existence of an alternative door can be found in every home of Arab descendants in Sugihwaras that have not changed. Nevertheless there are some homeowners who do not use the alternative door. The picture below is a few alternative doors located in Sugihwaras Arab Village and a small road (alley) to go directly to the private room inside the house. 


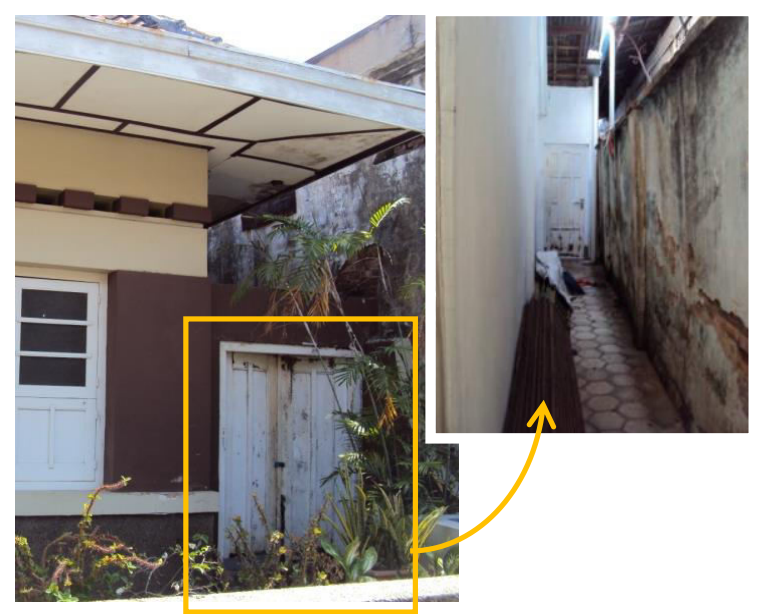

Fig. 6. The Woman's Path.

Another arrangement to maintain the privacy aspect inside the house is the high wall in each house that ensures to block the sight from outside. The existence of the second door between the guest room and family rooms became another manifest of privacy aspect.

\section{The Role of Sugihwaras Wakaf Mosque}

In the development of the mosque is a sign and symbol, belief, ritual and religious embodied in religious sociocultural institutions that are contained in the physical formation and the people in it. The mosque community is a product produced and brings traditional and modern elements. On the other hand, through the architecture can be explained the concepts that exist and interpret broadly. Thus the mosque can also be interpreted as a symbol of community life that is embodied in architecture as a religious expression (Imammudin, 1985). The Wakaf Sugihwaras Mosque was built around 1852. in the 1800s the city of Pekalongan was under Dutch Colonial rule. Indirectly the building of Wakaf Mosque Sugihwaras also has a building architecture style that is developing at that time that is colonial style of building or commonly referred to as Indische Landhuizen. It is seen from the symmetrical features of the building, has a shield roof, open impression, there are pillars on the front porch and back (Astuti, 2002).
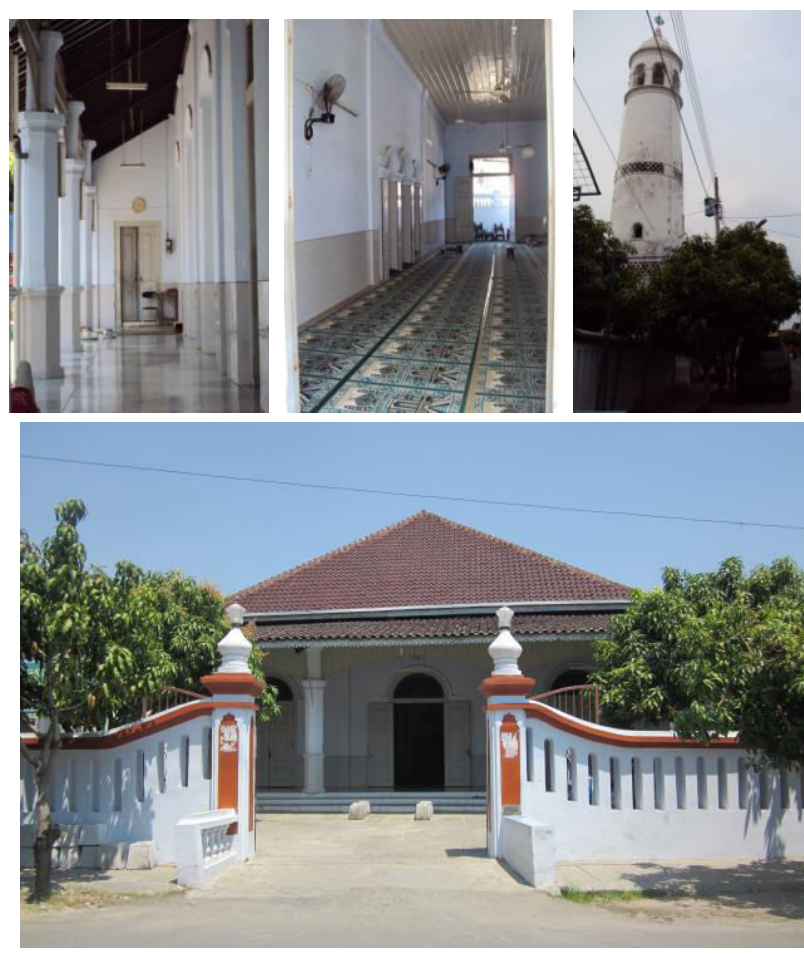

Fig. 7. Wakaf Mosque Sugihwaras.

Wakaf mosque Sugihwaras, as a place of worship, became a catalyst for community development. Some of these activities include regular recitation and discussion. Certain spaces within the mosque, the open space, the veranda, the praying hall, are used for religious activities and social activities. The activities which held in the mosque area show different character depend on the space that cover it. The closer to the mihrab the more intense and more important the activity could be.

\section{Conclusions}

The result shows that community who lives in Kampung Arab Sugihwaras especially the Arabian descendant preserving Islamic value in their social lives. But, modern urban culture faded some social rules away. While the physical principles based on Islamic value still applicable in their house especially for the privacy aspect and spatial order inside the house. Another result shows from the role of the Sugihwaras Wakaf Mosque. The activities which held in the mosque area show different character depend on the space that cover it. The closer to the mihrab the more intense and more important the activity could be.

\section{References}

Ahmad, Shaikh Mahmud dan M. Akram Khan. 1984. "Some Economic Issues: Reflections and Answers" dalam M. Tariq Quraishi (ed), Islam: A Way of Life and a Movement. Indianapolis: American Trust Publication

Abulughod, Janet. 1980. "Contemporary Relevance of Islamic Urban Principles". Dalam Ekistics Volume 47 Nomor 280 Januari/Febuari 1980 
Al-Bukhari, Muslim. 1960. "Saheeh Al-Bukhari" dalam Abdulbaqi, M (ed) Al-Maktabah Al-Falsafiyyah. Beirut

Asa, Kusnin, dkk. 2009. Mozaik Sejarah Pekalongan. Pekalongan: Pemerintah Daerah Kabupaten Pekalongan

Astuti, Sri Puji. 2002. "Rumah Tinggal Etnis Keturunan Arab di Pekalongan". Tesis tidak Dipublikasikan. Semarang: Magister Teknik Arsitektur Universitas Diponegoro.

Habraken, N Jhon. 1988. "Types of Social Agreement". The Collection of ACA-3 Conference Paper. Asian Congress of Architect. Korea

Imammudin, Abu H, Shamim Ara Hasun dan Debrashir Sarkar. 1985. Community Mosque: A Symbol of Society. Exploring Architecture in Islamic Culture. Regional Seminar in the Series Exploring Architecture. Bangladesh:17-22 Dec

Karim, Fazlul.1938. Al-Hadis: An English Translation and Commentary of 'Mishkatul Masabih' (compiled by Weli - al-Di ${ }^{-} \mathrm{n}$ Muhammad Ibn 'Abd-Allah al-Khatibal-Tabrizi (d. 737/1337), al-Mektab alIslami li al-"ibå‘ah wa al-Nashr, 1961),Vol. I. Calcutta

Karim, Fazlul.1938. Al-Hadis: An English Translation and Commentary of 'Mishkatul Masabih' (compiled by Weli al-Dinn Muhammad Ibn 'Abd-Allah alKhatibal-Tabrizi (d. 737/1337), al-Mektab al-Islami li al-"ibå'ah wa al-Nashr, 1961),Vol. I. Calcutta

Mortada, Hisham. 2003. Traditional Islamic Principles of Built Environment. London: Routledge Curzon

Petherbridge, Guy. 1987. Vernacular Architecture: The House and Society in Architecture of The Islamic Wolrd. London: Thames and Hudson

Rapoport, Amos. 1969. Home, Form and Culture. London: Prentice Hall Inc

Steenbribk, Karel A. 1984. Beberapa Aspek Tentang Islam di IndonesiaI. Jakarta: Bulan Bintang

Van Den Berg. LCW. 1989. Hadramaut dan Koloni Arab di Nusantara. Terjemahan: Rahayu Hidayat. Seri INIS Jilid 3. Jakarta: Perpustakaan Nasional INIS

Yusuf Al-Qaradawi. 1960. The Lawful and the Prohibited in Islam (AlOalalWal aaram Fil Islam). Indianapolis: American Trust Publication 